\title{
MONETARY POLICY EFFICIENCY IN CONDITIONS OF EXCESS LIQUIDITY WITHDRAWAL
}

\author{
Martin Mandel, Vladimír Tomšík*
}

\begin{abstract}
:
In case that a central bank is withdrawing excess liquidity, there arises a question whether the monetary policy based on repo operations (withdrawal repo) is identically efficient as the monetary policy relying on repo rate connected with reverse repo (issuance repo) when central banks provide liquidity. The analysis of this problem is a main subject of the article. Authors develop microeconomic model of commercial bank behaviour, which is used for the definition of conditions when the interest rate policy of central bank based alternatively on repo rates for repo and reverse repo operations is efficient. Statistical data (time series of $1998-2011$, monthly data frequency) are analysed and econometric verification of alternative forms of econometric models is performed. The authors arrived at a conclusion that the Czech National Bank's monetary policy operating in conditions of excess liquidity withdrawal through repo operations is efficient. In case of the Czech Republic an increase in repo rate on withdrawal repo should lead to an increase in interest rates of commercial banks and to a reduction in the credit activity of commercial banks and hence to the successful implementation of Czech National Bank's restrictive monetary policy.
\end{abstract}

Keywords: repo rate, transmission mechanism of monetary policy, Czech National Bank, econometric model

JEL Classification: E43, E47, E52, C12, C22

\section{Introduction}

Traditional interpretation of monetary policy is based on an assumption that central bank operates in conditions of "hunger" for liquidity and supplies liquidity to commercial banks through its monetary policy instruments. Approximately since the twenties of the

* Martin Mandel, University of Economics in Prague; Vladimír Tomšík, Czech National Bank and University of Economics in Prague. The article was supported by Project P402/12/G097 of the Grant Agency of the CR "DYME - Dynamic Models in Economy".

The authors note that everything contained in this paper represents their own views and not necessarily those of the Czech National Bank or the other institutions they represent. 
last century there has been a discussion how such liquidity should be supplied, what the specific role of open market operations and discount instruments should be like, i.e. of various forms of short-term credits of central bank (in greater detail see Revenda, 2010). ${ }^{1}$ Regardless whether a Keynesian, Post-Keynesian or monetarist approach was advocated, commercial banks have always been taken as agents that are exposed to the pressure of insufficient liquidity in the long run.

In this context "textbook" interpretation of the transmission mechanism of monetary policy considers central bank's interest rate (i.e. monetary policy rate) as the price at which central bank supplies liquidity to commercial banks. It is also true when central banks use to a larger extent reverse repo operations as a form of open market operations. ${ }^{2}$ Also in this case, the interpretation of transmission mechanism usually begins with reverse repo operation and respective repo rate.

Currently, some transition economies that have intervened in the foreign exchange market for a long time against the appreciation of domestic currency exchange rate, either due to a surplus balance of direct foreign investments or surplus trade balance, do not fit in this traditional scheme of monetary policy interpretation. ${ }^{3}$ Balance sheets of central banks in many transition economies, whose currencies have appreciated in the last ten years, are characterized not only by the long foreign exchange position when foreign exchange assets play a dominant role on the asset side of their balance sheet and significantly exceed foreign exchange liabilities but also by depositing excess resources of domestic liquidity by commercial banks with central bank in various forms of deposits (Table 1).

1 In the Czech economic literature this dispute was discussed for the first time between K. Engliš, who unambiguously advocated issuance policy based on short-term credits of central bank, and J. Macek, who besides the rediscount of bills of exchange supported the idea of purchasing government securities within open market operations (see Vencovský, 1997). After the World War II, open market operations have become of crucial importance in monetary policy in the majority of advanced countries. For technical aspects of the common functions of open market operations, discount policy and minimum required reserves see e.g. G.H. Sellon $(1980,1984)$.

2 The history of reverse repo operations performed by central banks dates back to the year 1917, when the Federal Reserve System started using these operations for the supply of liquidity to member commercial banks. Their renaissance and expansion occurred at the turn of the eighties and nineties of the last century (Vencovský, 1999 and Garbade, 2006).

3 In this article we will not deal with central banks that implemented the policy of the so called quantitative easing in the past (e.g. Bank of Japan, Fed, Bank of England and ECB). The analysis of this problem in the Czech economic literature see e.g. Frait, Horská and Melecký (2002), Mandel and Tomšík (2012). 
Table 1

Central Banks and Financial Structure of Their Balance Sheets (the case of transition economies)

\begin{tabular}{|c|c|c|c|}
\hline & $\begin{array}{l}\text { Share of net foreign assets } \\
\text { in the total volume of } \\
\text { balance-sheet assets }\end{array}$ & $\begin{array}{c}\text { Share of reserves and repo } \\
\text { operations in the total } \\
\text { volume of balance-sheet } \\
\text { assets }\end{array}$ & $\begin{array}{c}\text { Exchange rate } \\
\text { against USD } \\
(2005-2010)\end{array}$ \\
\hline Bulgaria & 0.31 & 0.21 & 0.07 \\
\hline Brazil & 0.38 & 0.52 & 0.38 \\
\hline Argentina & 0.55 & 0.30 & -0.24 \\
\hline India & 0.65 & 0.22 & -0.04 \\
\hline Thailand & 0.72 & 0.92 & 0.27 \\
\hline Chile & 0.81 & 0.59 & 0.10 \\
\hline Malaysia & 0.82 & 0.46 & 0.17 \\
\hline $\begin{array}{l}\text { Czech } \\
\text { Republic }\end{array}$ & 0.83 & 0.53 & 0.21 \\
\hline Columbia & 0.84 & 0.13 & 0.22 \\
\hline Russia & 0.86 & 0.16 & -0.07 \\
\hline Mexico & 0.89 & 0.42 & -0.14 \\
\hline South Africa & 0.90 & 0.43 & -0.13 \\
\hline Slovakia & 0.90 & 1.05 & 0.45 \\
\hline Israel & 0.92 & 0.86 & 0.20 \\
\hline China & 0.92 & 0.48 & 0.25 \\
\hline Lithuania & 0.94 & 0.18 & 0.06 \\
\hline Poland & 0.94 & 0.40 & 0.07 \\
\hline Hungary & 0.95 & 0.38 & -0.04 \\
\hline Romania & 0.97 & 0.33 & -0.08 \\
\hline Estonia & 0.97 & 0.50 & 0.07 \\
\hline Peru & 0.98 & 0.41 & 0.17 \\
\hline Latvia & 0.99 & 0.43 & 0.06 \\
\hline
\end{tabular}

Source: Annual reports of central banks of the particular countries and own calculation.

Note: + domestic currency appreciation, - domestic currency depreciation.

The Czech Republic is also a representative example in this sample. The Czech National Bank (CNB) intervened in the foreign exchange market against the appreciation of the Czech crown exchange rate until October 2002 (Holub 2004, Egert and Komárek 2005, Geršl and Holub 2006). ${ }^{4}$ In the subsequent period, the CNB indirectly influenced the exchange rate by repurchases of the government's privatization incomes outside

4 A more distinct exception since 1993 was the period of currency crisis in May 1997, when the CNB intervened against Czech crown depreciation at the volume of USD 2.5 billion (e.g. K. Šmídková, 1998 and O. Dědek, 2000). 
the foreign exchange market (ca. EUR 6 billion). It is also to state that in 2004-2011 the CNB realized conversions of cash flows connected with the EU funds (net inflow of approximately EUR 7 billion). The expansive effect of anti-appreciation foreign exchange interventions on the reserves of commercial banks (i.e. on the monetary base) was sterilized by the CNB at first through outright sales of the CNB treasury bills and then by repo operations. From the perspective of the $\mathrm{CNB}$, these were repo operations at the respective effective repo rate. From the point of view of commercial banks, these were "repo deposits". It is interesting that while in 1993 commercial banks held with the Czech central bank 12 hellers against one crown of customer deposits in the form of high liquid assets (voluntary and required reserves, CNB treasury bills, later repos), in 2003 it was unprecedented 42 hellers. A gradual decrease followed, and at the end of 2011 this orientative indicator of commercial bank liquidity was 16 hellers.

In case that central bank is withdrawing excess liquidity, there arises a question whether the monetary policy based on repo (withdrawal repo) operations and respective repo rate is identically efficient as the "textbook" monetary policy relying on repo rate connected with reverse repo (issuance repo) when central banks provides liquidity. The analysis of this problem is the main subject of our article.

In Chapter 2 of this article the interest rate transmission mechanism of monetary policy, on which the credit channel of monetary policy is based, is discussed. Results and conclusions of hitherto research are summarized while some estimates are updated including the phase of financial and economic crisis.

In Chapter 3 a microeconomic model of commercial bank behaviour is presented which is used for the definition of conditions when the interest rate policy of central bank based alternatively on repo rates for repo and reverse repo is efficient.

Chapter 4 is an empirical one. Statistical properties of time series are analysed and econometric verification of alternative forms of models is performed. In conclusion, the findings of our research are summarized.

\section{Interest Rate Transmission Mechanism of Monetary Policy and Findings of Empirical Research}

In the last fifty years central banks have applied a number of monetary policy transmission mechanisms that aspired to put into practice ideas of different theoretical schools and conceptions in the sphere of monetary policy. ${ }^{5}$ Let us cite at least Keynesian interest rate transmission mechanism, monetarist transmission mechanism relying on monetary base and money stock, and exchange rate transmission mechanisms based on a variant of fixed exchange rate. In the last ten years monetary policy based on inflation targeting

5 Readers can find detailed interpretation of monetary policy transmission mechanisms in foreign and Czech economic literature, e.g. in L. Horngren (1995), Šmídková (2002), M.S. Mohany and P. Turner (2008) and R. Mirdala (2009). 
has gained a dominant position. Inflation targeting was applied for the first time by the Reserve Bank of New Zealand in 1989. According to the International Monetary Fund statistics, at the end of 2011 this system was used by more than 40 countries. It has been used in Australia, Canada and the United Kingdom for a longer time. Among transition economies, it is applied in the Czech Republic, Poland, Hungary, Georgia, Romania and Serbia.

Inflation targeting, which belongs to the theoretical thinking of the so called "New Keynesians", implicitly assumes money stock and monetary base endogeneity (e.g. M. Sojka, 2010; J. Korda, 2010) and relies on the interest rate transmission mechanism; its sequence can be formulated as follows: short-term interest rate of central bank - short-term interest rate of money market - money market interest rate with longer maturity - deposit and lending customer interest rates. The scope of problems arising from the analysis of relations between these interest rates can be classified as follows:

1) relations based on arbitrage operations when the agent does not work with expected interest rate and only the interest rates known "in advance" (i.e. the quoted ones) are compared in qualitatively similar instruments with the same maturity,

2) relations based on speculations in the time horizon of the chosen yield curve when in line with the theory of expectations the agent compares long-term and in-advance known interest rates with short-term forward rates,

3) relations between the particular sectors and agents when interest rates from the interbank market are transmitted to the customer market represented by firms and households.

In the Czech economy (and/or in the CNB's monetary policy) the arbitrage practice of commercial banks includes the relation between two-week repo rate of central bank and rates of the interbank market in (two-week) PRIBOR or (two-week) PRIBID deposits. It can be logically justified because each commercial bank takes a decision whether to deposit free resources with the central bank at (two-week) repo rate or to lend them to another commercial bank at (two-week) PRIBOR rate or to deposit them with another commercial bank at (two-week) PRIBID rate. If central bank is present in the market all the time, if it fully satisfies all agents in repo tenders for liquidity withdrawal and at the same time if there is no greater difference in the risk profile of the particular players, there is no reason for distinctly different development of these three rates in time. Due to perfectly functioning arbitrage there exists a close correlation between the rates concerned that was proved by empirical research using different econometric approaches (e.g. V. Izák, 1998, Z. Dvorný, 2002 and J. Brada and K. Brůna, 2004). 
Figure 1

Development of (two-week) Repo Rate and (two-week) PRIBOR since January 1996

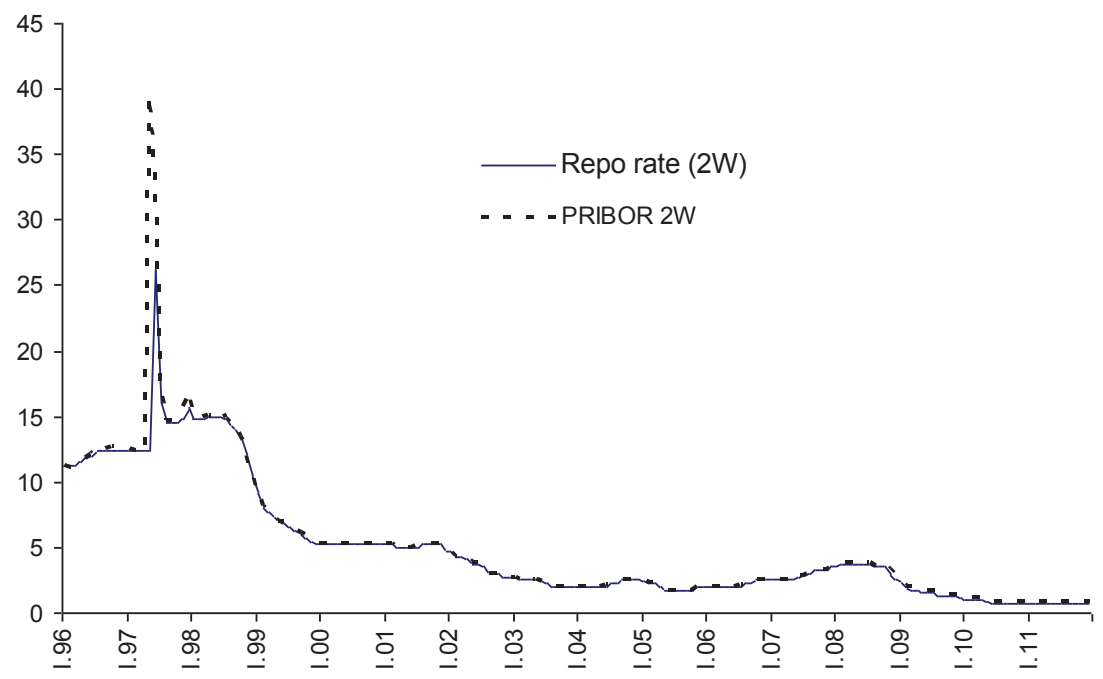

Source: CNB

Note: The value of correlation coefficient is 0.93 .

For the "transmission of information" along the yield curve between interest rates with different maturity date, e.g. (two-week) PRIBOR - (3-month) PRIBOR - (6-month) PRIBOR - (12-month) PRIBOR, such closeness of relations cannot be assumed because these are relations operating with the expected development of interest rates, with estimation of liquidity and market risk premiums (e.g. J. Arlt, J. and Š. Radkovský, 2000; V. Kotlán, 1999; J. Brada and K. Brůna, 2004). Commercial banks have to consider whether the central bank will not change its interest rate in a longer period and whether it will fully satisfy demand in repo tenders all the time. Besides, they evaluate their interest rate policy towards the government, firms and households because with longer maturities alternative opportunities for granting credits and for investments arise. The transmission mechanism is weakened especially in times of financial crisis when dealings of banks with excess liquidity are almost exclusively reduced to relations with the central bank. Quoted PRIBOR rates with maturity longer than two weeks practically become fictitious at which no real dealings are realized in the interbank market. ${ }^{6}$ As e.g. (three- or six-month) PRIBOR interest rate plays a role of reference interest rate for floating lending interest rates, there is a threat that commercial banks will set it "purposefully" according to customers' estimated solvency. Besides (two-week) repo rate, the development of PRIBOR interest rates with longer maturity reflects the development of perceived risk

6 It is questionable whether these rates are not de facto fictitious even in "normal" times because banks are not obliged to have dealings with each other at quoted interest rates. Nevertheless, the transmission mechanism is based on the fact that PRIBOR interest rate is used as the basic reference rate for granting credit. 
in the interbank market, and in general, in the whole economy at the time of increased uncertainty or crisis.

Figure 2

Development of Two-Week, Three-Month, Six-Month and One-Year PRIBOR since January 1993

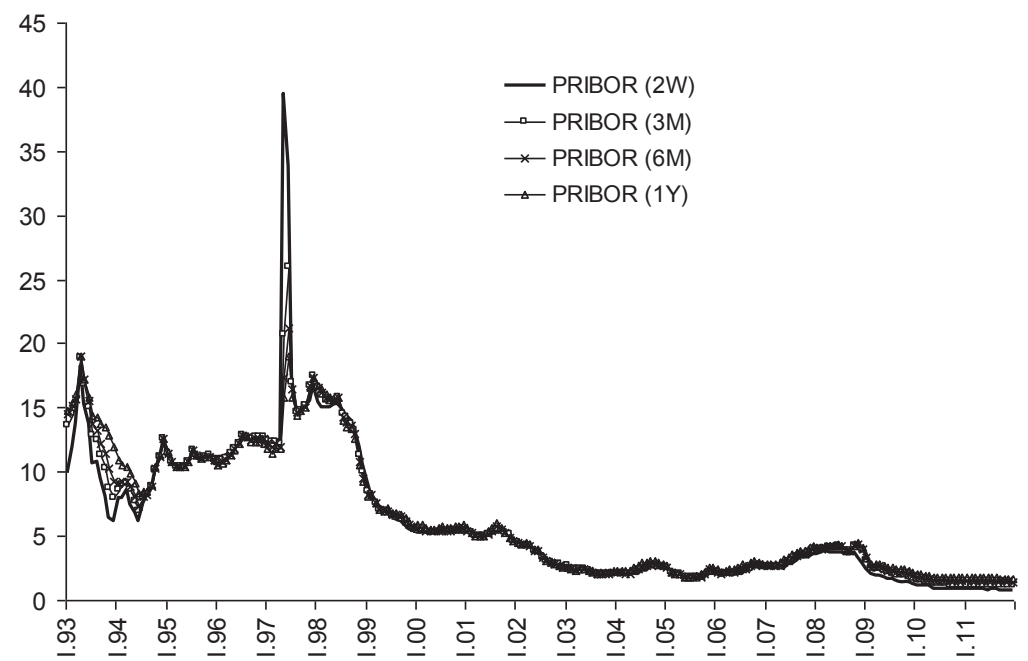

Source: CNB

Table 2

Correlation Coefficients

\begin{tabular}{|l|c|c|c|}
\hline Period & $\begin{array}{c}\text { Correlation coefficient } \\
\text { between 2W PRIBOR } \\
\text { and 3M PRIBOR }\end{array}$ & $\begin{array}{c}\text { Correlation coefficient } \\
\text { between 2W PRIBOR } \\
\text { and 6M PRIBOR }\end{array}$ & $\begin{array}{c}\text { Correlation coefficient } \\
\text { between 2W PRIBOR } \\
\text { and 1Y PRIBOR }\end{array}$ \\
\hline $1993-2011$ & 0.964545 & 0.940753 & 0.918408 \\
\hline $1998-2011$ & 0.997238 & 0.994243 & 0.990861 \\
\hline $1998-2007$ & 0.998209 & 0.995977 & 0.992727 \\
\hline $2008-2011$ & 0.992129 & 0.990862 & 0.98906 \\
\hline
\end{tabular}

Table 3

Correlation Coefficients

\begin{tabular}{|l|c|c|c|}
\hline Period & $\begin{array}{c}\text { Correlation coefficient } \\
\text { between change in 2W } \\
\text { PRIBOR and change } \\
\text { in 3M PRIBOR }\end{array}$ & $\begin{array}{c}\text { Correlation coefficient } \\
\text { between change in 2W } \\
\text { PRIBOR and change } \\
\text { in 6M PRIBOR }\end{array}$ & $\begin{array}{c}\text { Correlation coefficient } \\
\text { between change in 2W } \\
\text { PRIBOR and change } \\
\text { in 1Y PRIBOR }\end{array}$ \\
\hline $1993-2011$ & 0.797988 & 0.710116 & 0.622137 \\
\hline $1998-2011$ & 0.881759 & 0.812761 & 0.743784 \\
\hline $1998-2007$ & 0.893516 & 0.821474 & 0.748734 \\
\hline $2008-2011$ & 0.751253 & 0.703664 & 0.663667 \\
\hline
\end{tabular}


The transmission of interest rates from sector to sector, especially from interbank market to customer market, may be connected with the problem of a different degree of competition. While the interbank market is generally considered as a perfectly competitive one, the relation to customers may show features of imperfect competition. A typical feature of oligopolistic behaviour on the side of bank products supply is e.g. the use of the principle of two-way quotation in the interbank market and one-way quotation in relation to customers (particularly to "smaller" customers). A characteristic feature of an oligopoly is a partial transmission of costs imposed on banks by the government or the central bank (e.g. costs incurred by tax increase, by introduction of compulsory deposit insurance, by an increase in rates on minimum required reserves, an increase in repo rate on repo, etc.) to customers through a higher interest margin. Another feature of oligopolistic behaviour of banks may be the asymmetric reaction to an increase and retrograde decrease in externally imposed costs when in the case of a decrease in the costs banks in the oligopolistic position postpone a decrease in interest margin. The fact that the degree of competition in the banking sector influences the level of interest margin and the reaction of interest margin to the interest rate policy of central bank was supported to a larger extent by conclusions of empirical research, e.g. T. S. Y. Ho and A. Saunders, 1981; A. Demirgüc-Kunt and H. Huizinga, 1999; S. Corvoisier and R. Gropp, 2001; K. Brůna, 2007. However, it is not possible to speak about perfect competition on the side of demand for bank products. Customers of banks are "numerous", but they are not a homogeneous group in any case. It is not so important in offered deposit products, but it is crucial in credit products. In reaction to this problem Post-Keynesian economists (e.g. Moore, 2006) formulated a hypothesis about credit allocation. ${ }^{7}$

Under these circumstances we will focus on the accommodation of a "standard" microeconomic model of perfectly competitive market to some specific conditions of the bank market.

\section{Interest Rate Transmission Mechanism and Credit Channel in Terms of a Microeconomic Model of a Commercial Bank's Behaviour}

Using a microeconomic model describing the behaviour of a commercial bank we will explain a difference in the impacts of restrictive monetary policy based alternatively on repo and reverse repo operations. We will be interested in the problem of transmission of changes in central bank's repo rate to lending (and/or deposit) customer interest rates; and subsequently, under what conditions an increase in repo rate would lead to the restriction of bank credit supply. Our analysis will be aimed at the Czech Republic, where (since the mid-nineties) commercial banks have traditionally operated in conditions of "excess" liquidity that was created by central bank through foreign exchange interventions against the appreciation of domestic currency exchange rate. ${ }^{8}$

7 In the Czech economic literature the problem of credit allocation was studied in detail e.g. by Buliř (1992), Kodera and Mandel (1997).

8 It will be an aggregate approach. As for the division of the Czech banking sector into "large" and "small" banks, we will mainly deal with "large" ones. 
While an increase in repo rate on reverse repo causes an increase in the costs of commercial banks, under restrictive monetary policy implemented through an increase in repo rate on repo yields of commercial banks are rising. ${ }^{9}$ Under restrictive monetary policy implemented through an increase in interest rate on reverse repo the transmission mechanism of monetary policy is based on gradual transmission of the cost burden from commercial banks to their customers. Under restrictive monetary policy implemented through an increase in interest rate on repo the arbitrage behaviour of commercial banks plays its role that takes a decision on the particular financial assets.

A microeconomic approach studies the influence of the central bank on volume of loans granted by commercial banks. In our case we will alternatively consider the influence of repo rate in reverse repo $\left(I R_{E}\right)$ and the influence of repo rate in repo $\left(I R_{S}\right)$. The symbol for lending interest rate of commercial banks will be $I R_{L}$ and for deposit interest rate (i.e. in direct debit) $I R_{D}$.

The yields $(B)$ of a commercial bank are defined by this equation:

$$
B=I R_{L} \cdot L+I R_{S} \cdot R E P O_{S}
$$

Yields of a commercial bank are connected with operations on the side of assets, i.e. with the granting of loans $(L)$, and with deposition of resources with central bank as repo deposits (i.e. from the aspect of monetary policy these are withdrawal $R E P O_{S}$ ). ${ }^{10}$

Costs $(C)$ of a commercial bank are expressed by this relation:

$$
C=I R_{D} \cdot D+I R_{E} \cdot R E P O_{E}+c_{L} \cdot L^{2}+c_{I R} \cdot I R_{L} \cdot L
$$

where in parameters $c_{L}$ and $c_{I R}$ the following intervals of values are assumed $c_{L}>0$ and $0<c_{I R}<1$.

Let us assume that total costs are related to the level of interest paid on customer deposits $\left(I R_{D} \cdot D\right)$ and to the level of interest paid on accepted repo credits from central bank $\left(I R_{E} \cdot R E P O_{E}\right)$. They are also related to the second power of the volume of granted loans $(L)$ and to the volume of required interest on loans $\left(I R_{L} \cdot L\right)$. The second power in the explanatory variable $L$ approximately expresses the fact that with the larger volume of granted loans the costs of banks incurred by creation of provisions (and/or reserves) increase progressively, especially with transition from investment to speculative grade of the rating scale. ${ }^{11}$ The last term of addition on the right side of the cost equation indicates that the growth of the interest volume required by the bank increases the probability of default of firms granted credits.

9 An impact on the profit and loss statement of central bank is opposite to that in commercial banks.

10 For simplification minimum required reserves (PMR) not bearing interest are assumed.

11 In this case we do not speak about International Financial Reporting Standards IFRS, but we formulate a hypothesis about the relation between rating groups and probability of default. This hypothesis allows to classify ratings into investment and speculative grade and is empirically documented by all important rating agencies. 
The balance identity of a commercial bank is expressed by the equality

$$
R E P O_{S}+P M R+L=R E P O_{E}+D,
$$

where the side of balance assets is given by the volume of repos, level of minimum required reserves and by the volume of granted credits. ${ }^{12}$ The side of balance liabilities is given by the volume of reverse repos and the level of customer deposits.

A relatively high degree of money endogeneity is assumed that is typical of inflation targeting policy. Commercial banks decide on the volume of repos and reverse repos by means of their demand. The level of repo rates is set by central bank. The volume of reverse repos decreases with an increase in repo rate $\left(I R_{E}\right)$ because commercial banks reduce their demand for lending resources acquired from central bank.

$$
R E P O_{E}=m_{O}-m \cdot I R_{E}
$$

Demand of commercial banks for repo deposits (i.e. repos) is related to the liquidity policy of commercial banks, i.e. to the rate of liquidity held against customer deposits $\left(r_{R E P O S}\right)$ and to the level of repo rate $\left(I R_{S}\right)$.

$$
R E P O_{S}=r_{R E P O S} \cdot D+w \cdot I R_{S}
$$

The level of minimum required reserves is given by the volume of customer deposits and demanded rate on minimum required reserves $\left(r_{P M R}\right)$.

$$
P M R=r_{P M R} \cdot D
$$

In the framework of the interest rate transmission mechanism it is assumed that in their interest rate policy towards customers commercial banks react to central bank's interest rate policy represented by repo rate in repo and/or reverse repo.

$$
\begin{aligned}
& I R_{L}=b_{0}+b \cdot I R_{E} \\
& I R_{L}=l_{0}+l \cdot I R_{S} \\
& I R_{D}=q_{0}+q \cdot I R_{E} \\
& I R_{D}=g_{0}+g \cdot I R_{S}
\end{aligned}
$$

Hypotheses about the reaction of customer interest rates to central bank's interest rates under perfect and imperfect competition are formulated below in the text.

12 For simplification voluntary reserves are not considered. Such simplification would apparently be inacceptable if central bank offered reverse repo operations with long maturity only. 
Two versions of balance identity of a commercial bank are considered:

a) for the central bank operating exclusively with reverse repo in its monetary policy

$$
\begin{gathered}
P M R+L=R E P O_{E}+D \\
r_{P M R} \cdot D+L=m_{O}-m \cdot I R_{E} \cdot D \\
\frac{L-\left(m_{O}-m \cdot I R_{E}\right)}{\left(1-r_{P M R}\right)}=D
\end{gathered}
$$

b) for the central bank operating exclusively with repo in its monetary policy

$$
\begin{gathered}
R E P O_{S}+P M R+L=D \\
r_{R E P O S} \cdot D+w \cdot I R_{S}+r_{P M R} \cdot D+L=D \\
\frac{w \cdot I R_{S}+L}{\left(1-r_{R E P O S}-r_{P M R}\right)}=D
\end{gathered}
$$

\section{The case of the central bank with reverse repo}

In the case that central bank operates only on the basis of reverse repo, the profit of a commercial bank $(P)$ is expressed as follows:

$$
P=B-C=I R_{L} \cdot L-I R_{D} \cdot D-I R_{E} \cdot R E P O_{E}-c_{L} \cdot L^{2}-c_{I R} \cdot I R_{L} \cdot L
$$

After substitution of behavioural and technical relations (incl. balance identity) we get the equation

$$
\begin{gathered}
P=b_{0} \cdot L+b \cdot I R_{E} \cdot L-q_{0} \cdot \frac{L-\left(m_{O}-m \cdot I R_{E}\right)}{1-r_{P M R}}-q \cdot I R_{E} \cdot \frac{L-\left(m_{O}-m \cdot I R_{E}\right)}{1-r_{P M R}}- \\
-I R_{E} \cdot\left(m_{0}-m \cdot I R_{E}\right)-c_{L} \cdot L^{2}-c_{I R} \cdot b_{0} \cdot L-c_{I R} \cdot b \cdot I R_{E} \cdot L
\end{gathered}
$$

A commercial bank maximizes profit with respect to repo rate on reverse repo

$$
\frac{\partial P}{\partial I R_{E}}=b \cdot L-\frac{q_{0} \cdot m}{1-r_{P M R}}-\frac{q \cdot L}{1-r_{P M R}}+\frac{q \cdot m_{0}}{1-r_{P M R}}-\frac{2 \cdot q \cdot m \cdot I R_{E}}{1-r_{P M R}}-m_{0}+2 \cdot m \cdot I R_{E}-c_{I R} \cdot b \cdot L=0
$$

In the case of efficient monetary policy when an increase (a decrease) in central bank's rates leads to a decrease (an increase) in granted credits, it must hold good

$$
L=\frac{\frac{q_{0} \cdot m}{1-r_{P M R}}-\frac{q \cdot m_{0}}{1-r_{P M R}}+\frac{2 \cdot q \cdot m \cdot I R_{E}}{1-r_{P M R}}+m_{0}-2 \cdot m \cdot I R_{E}}{b \cdot\left(1-c_{I R}\right)-\frac{q}{1-r_{P M R}}}
$$




$$
\frac{\partial L}{\partial I R_{E}}=-\frac{2 \cdot m \cdot\left(1-q-r_{P M R}\right)}{b \cdot\left(1-c_{I R}\right) \cdot\left(1-r_{P M R}\right)-q}<0
$$

From the perspective of our model there is a number of combinations when restrictive monetary policy is efficient, i.e. an increase in repo rate leads to a decrease in the supply of credits by commercial banks. The following case can be considered as common when it simultaneously holds good that

a) $m>0$, i.e. commercial banks reduce the volume of reverse repos received from the central bank at increasing repo rate,

b) $1>b>q$, i.e. lending interest rates are more sensitive to a change in repo rate than deposit interest rates, sensitivities are however smaller than 1 ,

c) $c_{I R}<1$, i.e. costs of an increase in lending interest rate do not exceed yields from an increase in lending interest rate,

d) $r_{P M R}<1$ i.e. the rates on minimum required reserves are smaller than 1 .

If repo rate on reverse repo $\left(I R_{E}\right)$ increases, commercial banks want to reduce the volume of loans acquired from central bank $(m>0)$ and to replace it by a higher volume of accepted customer deposits that "will be attractive" through higher deposit rates $\left(I R_{D}\right)$. But the total volume of money stock is constant in a short period. So a commercial bank can acquire new customer deposits only at the expense of another commercial bank. An increase in deposit interest rates can be expected only under perfect competition. If commercial banks represent an oligopoly vis-à-vis non-bank customers, they will tend not to increase deposit interest rates and will prefer the strategy of cost transmission to customers through lending interest rates $\left(I R_{L}\right)$, i.e. the policy of a higher interest margin. Then $b>q$ can be expected. Such policy could be avoided for fear that the costs of an increase in lending interest rates will exceed the yields from an increase in lending interest rates, due to an increase in customers' insolvency (i.e. item $c_{I R}>1$ ).

\section{The case of central bank with repo}

In case that the central bank operates only on the basis of repo, the profit of a commercial bank $(P)$ is expressed as follows:

$$
P=B-C=I R_{L} \cdot L+I R_{S} \cdot R E P O_{S}-I R_{D} \cdot D-c_{L} \cdot L^{2}-c_{I R} \cdot I R_{L} \cdot L
$$

After substitution of behavioural and technical relations (incl. the balance identity) we get the equation

$$
\begin{gathered}
P=l_{0} \cdot L+l \cdot I R_{S} \cdot L+I R_{S} \cdot\left(r_{R E P O S} \cdot \frac{w \cdot I R_{S}+L}{1-r_{R E P O S}-r_{P M R}}+w \cdot I R_{S}\right)- \\
-g_{0} \cdot \frac{w \cdot I R_{S}+L}{1-r_{R E P O S}-r_{P M R}}-g \cdot I R_{S} \cdot \frac{w \cdot I R_{S}+L}{1-r_{R E P O S}-r_{P M R}}-c_{L} \cdot L^{2}-c_{I R} \cdot l_{0} \cdot L-c_{I R} \cdot l \cdot I R_{S} \cdot L
\end{gathered}
$$


A commercial bank maximizes profit in relation to repo rate on repo ${ }^{13}$

$$
\begin{gathered}
\frac{\partial P}{\partial I R_{S}}=l \cdot L+\frac{2 \cdot r_{R E P O S} \cdot w \cdot I R_{S}}{1-r_{R E P O S}-r_{P M R}}+\frac{r_{R E P O S} \cdot L}{1-r_{R E P O S}-r_{P M R}}+2 \cdot w \cdot I R_{S}- \\
-\frac{g_{0} \cdot w}{1-r_{R E P O S}-r_{P M R}}-\frac{2 \cdot w \cdot g \cdot I R_{S}}{1-r_{R E P O S}-r_{P M R}}-\frac{g \cdot L}{1-r_{R E P O S}-r_{P M R}}-c_{I R} \cdot l \cdot L=0 \\
L=\frac{-2 \cdot w \cdot\left(1-g-r_{P M R}\right) \cdot I R_{S}+g_{0} \cdot w}{l \cdot\left(1-c_{I R}\right) \cdot\left(1-r_{R E P O S}-r_{P M R}\right)+r_{R E P O S}-g} \\
\frac{\partial L}{\partial I R_{S}}=-\frac{2 \cdot\left(1-g-r_{P M R}\right)}{l \cdot\left(1-c_{I R}\right) \cdot\left(1-r_{R E P O S}-r_{P M R}\right)+r_{R E P O S}-g} \cdot<0
\end{gathered}
$$

The volume of granted credits $(L)$ is a function of repo rate on repo $\left(I R_{S}\right)$.

Theoretically, there is a number of combinations again when restrictive monetary policy is efficient, i.e. an increase in repo rate leads to a decrease in the supply of credits by commercial banks. Monetary policy is efficient, e.g. when it simultaneously holds good

a) $w>0$, i.e. commercial banks increase the volume of repo deposits with central bank if repo rate increases,

b) $g=0$, i.e. commercial banks do not increase deposit interest rates if repo rate increases (already discussed in the preceding case),

c) $l>0$, i.e. commercial banks transmit higher repo rates to higher lending interest rates,

d) $c_{I R}<1$, i.e. the costs of an increase in lending interest rate does not exceed the yields from an increase in lending interest rates,

d) $r_{R E P O S}=0$, i.e. demand for repo deposits is zero by virtue of customer deposits.

This case is "extreme" to some extent and the strong oligopolistic behaviour of banks is assumed again. With an increase in repo rate on repo $\left(I R_{S}\right)$ the yields of commercial banks are increasing. In the framework of profit maximization policy and/or in line with arbitrage practice commercial banks may require higher lending interest rates. On the other hand, customer deposit rates are not increased because the profit of banks would decrease. It results in an increase in interest margin.

In terms of formulating hypotheses it is possible to describe an opposite "extreme" case when restrictive monetary policy based on an increase in repo rate is inefficient. If repo rate increases, banks are not under direct pressure of cost growth and profit decrease. Therefore they can choose an absolutely passive strategy of "doing nothing" (i.e. the case when $w=0$ and $l=0$ ) which will also ensure their higher profit thanks to higher repo rate on repo. This passive policy will also be supported by the fact that commercial banks cannot know in advance whether the costs incurred by an increase in lending

13 Commercial banks response on central bank repo rate policy in order to maximize their profit. 
interest rates due to an increase in customers' insolvency will not exceed the yields from an increase in lending interest rates (i.e. the case $c_{I R}>1$ ).

\section{Empirical Analysis and Its Results}

The choice of an economic model and its subsequent mathematical formalization predetermine to a large extent the character of model parameters (boundary slopes or elasticity), which should be included in the model. Linear models, which are based on national accounting identities expressed as the sum of (difference in) variables, do not allow the transformation of a model to relative changes (and/or changes in logarithms). Hence it is necessary to use level data and/or their changes and parameters in the form of marginal propensities.

Econometric model and its empirical verification are, however, subject to other criteria. For instance the problem of time series non-stationarity "can force us" to transform level data to their relative changes (and/or changes in logarithms). The resultant estimated coefficients of an econometric model are in the form of elasticities, which is not compatible with marginal propensities in a mathematical model.

Data were acquired from the ARAD time series database of the CNB with the exception of the time series of industrial production that was taken from the Czech Statistical Office database. The studied period was from January 1998 to December 2011, i.e. monthly data frequency. Only the time series of classified loans was used from January 2005 due to comparability because different methodology was used for reporting classified loans in the preceding period.

Table 4

Results of Augmented Dickey-Fuller Unit Root Test (model with constant, no trend)

\begin{tabular}{|l|c|c|c|c|}
\hline \multirow{2}{*}{} & \multicolumn{2}{|c|}{ Level data } & \multicolumn{2}{c|}{$\begin{array}{c}\text { Annual relative changes } \\
\text { in variables }\end{array}$} \\
\cline { 2 - 5 } & $\begin{array}{c}\text { Critical value } \\
\text { (5\% significance } \\
\text { level) }\end{array}$ & $\begin{array}{c}\text { Reached } \\
\text { value }\end{array}$ & $\begin{array}{c}\text { Critical value } \\
\text { (5\% significance } \\
\text { level) }\end{array}$ & $\begin{array}{c}\text { Reached } \\
\text { value }\end{array}$ \\
\hline Repo rate & -2.8792 & -5.1468 & - & - \\
\hline Deposit rate & -2.8792 & -4.7244 & - & - \\
\hline Credit rate & -2.8787 & -5.8858 & - & - \\
\hline Repo (withdrawal) & -2.8801 & -2.0163 & -2.8787 & -3.3553 \\
\hline Currency in circulation & -2.8787 & -0.3713 & -2.8787 & $-2.4352^{*}$ \\
\hline Foreign exchange reserves & -2.8787 & -1.7416 & -2.8787 & $-2.8386^{*}$ \\
\hline Credits & -2.8794 & -0.8899 & -2.8788 & -4.3706 \\
\hline Classified loans & -2.8789 & -1.6420 & -2.8789 & $-2.5188^{*}$ \\
\hline Deposits & -2.8787 & 0.9039 & -2.8787 & -3.0758 \\
\hline Industrial production & - & - & -2.8790 & -2.9974 \\
\hline
\end{tabular}

Note: * Stationary at a $10 \%$ significance level. 
The results of the unit root tests (Augmented Dickey-Fuller Unit Root test, Table 4) indicate that while interest rates in the studied period 1/1998 - 12/2011 are stationary already in their levels, other studied variables are stationary only when annual relative changes are used. This limits the scope for econometric verification of parameters.

\subsection{Econometric models of repo deposits of commercial banks}

The estimation of repo deposit sensitivity to central bank's repo rate can be formulated as a two-equation structural economic model of demand for repo deposits and supply of repo deposits. ${ }^{14}$ The demand for repo deposits $\left(R E P O_{S}{ }^{D}\right)$ is a function of repo rate, currency in circulation $(C U R)$, deposits $(D)$ and foreign exchange reserves $(F R)$. The supply of repo deposits $\left(R E P O_{S}^{S}\right)$ is a function of repo rate $\left(I R_{S}\right)$.

$$
\begin{gathered}
R E P O_{S}^{D}=f\left(I R_{S}, C U R, D, F R\right) \\
R E P O_{S}^{S}=f\left(I R_{S}\right)
\end{gathered}
$$

Direct estimation of demand function by the least-squares method under the existence of a two-equation structural model (of the supply - demand type) may be connected with the problem of inconsistent estimations of parameters when random error is correlated with the price variable (i.e. with repo rate in our case). This problem does not arise in the estimation of supply function, only when the supply function is absolutely elastic (Maddala and Lahiri, 2010; J. Arlt and M. Arltová, 2007). It is to note that this is just the case corresponding to the character of monetary policy based on inflation targeting. In an effort to maintain targeted interest rate, the central bank creates an infinitely elastic supply of repo deposits that are to withdraw excess liquidity in the market and thereby stabilizes the market interest rate in the interbank market at a required level. From an economic system perspective, supply adjusts to demand immediately. This mechanism of implementing monetary policy justifies the use of one-equation model.

\section{Model with relative annual changes in variables}

Having chosen the model with relative annual changes in variables and with $A R(I)^{15}$ process and using the least-squares method the following results were obtained:

$$
\begin{aligned}
& \text { repo }_{S, t}=3.0172+6.1069 \cdot \mathrm{ir}_{S, t}-0.4559 \cdot \mathrm{cur}_{t}+2.0081 \cdot d_{t}+1.2880 \cdot f r_{t}+0.8253 \cdot A R(1) \\
& \begin{array}{lllll}
(0.2224) & (4.3873) & (-0.5714) & (2.1829) & \text { (3.8706) }
\end{array} \\
& \mathrm{n}=167 \\
& \text { R-sq } 0.6294 \\
& \text { F-stat } 54.687 \text { (0.0000) }
\end{aligned}
$$

14 We assume that an economic system and central bank policy together ensure reaching balance between demand and supply of repo deposits.

15 It is the first order autoregressive process between residuals of the estimated model in time $t$ and $t-1$. 
The parameter in front of the variable of currency in circulation (cur) has the sign consistent with the hypothesis, but it is statistically insignificant. The reason is apparently multicollinearity indicated by a high value of the coefficient of correlation between currency in circulation and deposits (0.88). Having excluded currency in circulation from the set of explanatory variables, the following results were obtained:

$$
\begin{aligned}
\text { repo }_{S, t}= & 1.3804+6.3212 \cdot i r_{S, t}+2.1292 \cdot d_{t}+1.2587 \cdot f r_{t}+0.8306 \cdot A R(1) \\
& (0.1194)(4.6379) \quad(2.3441)
\end{aligned}
$$

$\mathrm{n}=167$

R-sq 0.6287

F-stat $68.568(0.0000)$

All signs are consistent with hypotheses. Parameters (with the exception of the constant) are different from zero at a 5\% significance level. Neither Q-statistic nor LM test indicates the existence of the $1^{\text {st }}-12^{\text {th }}$ order serial correlation of residuals. The Breusch-PaganGodfrey test of heteroscedasticity does not reject the hypothesis about homoscedasticity because regression of the variance of residuals on explanatory variables (repo rate, deposits and foreign exchange reserves) is statistically insignificant. An increase in the growth rate of repo deposits of commercial banks with the central bank is motivated by an increase in the magnitude of the change in repo rate. On the contrary, an increase in the growth rate of deposits on customers" side leads "in the short term" to an increase in the growth rate of repo deposits of commercial banks with central bank. Interventions against the Czech crown appreciation connected with an increase in the growth rate of central bank foreign exchange reserves and commercial banks excess reserves are also followed by an increase in the growth rate of deposits as a result of the central bank's sterilization policy. In the long run, commercial banks do not prefer holding excess reserves due to their low profitability.

\section{Cointegration analysis and vector error correction model (level data)}

Cointegration analysis makes it possible to analyse long-term equilibrium relations among the studied variables. The above-chosen diagnostic methods indicate that the time series of repo deposits, deposits, currency in circulation and foreign exchange reserves are of type I(1). Problem is that the time series of deposits and currency in circulation are "strongly" correlated (correlation coefficient 0.88). The results of cointegration analysis (normalized cointegration coefficients) using the vector error correction model are as follows:

$$
\begin{aligned}
& 0=1 \cdot R E P O_{S, t}+0.9623 \cdot C U R_{t}-1.0550 \cdot F R_{t}+59.40 \quad E C M=-0.2025 \\
& (5.5661) \quad(-9.2790) \\
& (-3.4661) \\
& \mathrm{n}=166 \\
& \text { R-sq } 0.3061
\end{aligned}
$$$$
\text { F-stat } 14.11
$$ 


$$
0=1 \cdot R E P O_{S, t}+0.1598 \cdot D_{t}-1.0760 \cdot F R_{t}+38.473 \quad E C M=-0.2622
$$

$\mathrm{n}=166$

F-stat 13.45

R-sq 0.2959

In both cases the Johansen cointegration test identified 1 cointegration vector at a 5\% significance level. The values of the coefficients of ECM adjustment speed are within the required interval $(-1,0)$. With the exception of deposits, the signs are consistent with introductory hypotheses (similarly like in a short-term model based on relative changes). The opposite sign in the parameter at the variable of deposits indicates that short-term processes are functioning in a different way than are long-term relations. In the long run, the endogenous growth of deposits, i.e. Post-Keynesian approach "credits create deposits", is connected with the transformation of free liquidity in the form of repo deposits to minimum required reserves.

\subsection{Models describing relations among interest rates}

Monetary policy of inflation targeting is based on the interest rate transmission channel. In Chapter 2 it was stated that in terms of correlation analysis the interest rate transmission mechanism in the money market segment shows the properties of a "good transmission system" in the long run. However, this is a partial finding only. Important is the resulting transmission between the central bank's repo rate on the one hand and deposit and lending customer rates on the other hand. An increase in repo rate leads to a decrease in bank credits if lending interest rate subsequently increases and deposit interest rate does not increase "too much". Fulfilment of the above-derived condition for monetary policy efficiency depends on the particular values of sensitivity parameters.

Our final estimates of parameters (by the least-squares method) in regression equations for the relation between repo rate $\left(I R_{S}\right)$ and deposit interest rate $\left(I R_{D}\right)$ and/or lending interest rate $\left(I R_{L}\right)$ are as follows:

$\mathrm{n}=168$

$$
I R_{D}=-0.0103+0.4072 \cdot I R_{S}
$$

R-sq 0.6267

F-stat $278.71(0.0000)$

DW stat 2.0210

$\mathrm{n}=168$

$$
\begin{gathered}
I R_{L}=-0.0157+0.7420 \cdot I R_{S} \\
(-0.9779)(12.241)
\end{gathered}
$$

R-sq 0.4744

F-stat 149.85 (0.0000)

DW stat 2.1383 
The estimated parameters document that an increase in repo rate leads to an increase in both customer interest rates concerned. The finding that lending interest rates are more responsive than deposit interest rates does not contradict previous research (e.g. Brůna, 2007).

\subsection{Models describing the sensitivity of bank costs to an increase in interest rate}

Based on the above-formulated microeconomic cost function, we formulated the basic functional relation for subsequent estimation of the influence of a change in lending interest rates on bank costs as follows:

$$
C L=f\left(I_{L}, I P\right)
$$

The volume of classified loans $(C L)$ represents a proxy variable for the costs of banks incurred by bad debt writes-off. We are examining the sensitivity of this item to the volume of required interest $\left(I_{L} I R_{L} \cdot L\right)$. The index of industrial production $(I P)$, which captures the influence of the business cycle, is included as a significant explanatory variable. Due to time series stationarization a particular form of a VAR econometric model was based on annual relative changes (Hušek, 1999). Experimental estimations showed that the VAR model is a suitable one because a statistically significant relation was proved between the annual change in industrial production and annual change in lending interest rate (the growth of industrial production leads to an increase in lending interest rate). The particular form we used was VAR (1) because higher lag orders did not result in higher quality of estimates. We present only the equation with classified loans as dependent variable

$$
\begin{gathered}
c l_{t}=0.6206+0.9386 \cdot c l_{t-1}-0.1328 \cdot i p_{t-1}+0.0373 \cdot i_{L, t-1} \\
\quad(1.0903)(35.520) \quad(-3.8797)
\end{gathered}
$$

$\mathrm{n}=81(4 / 2005-12 / 2011)$

R-sq 0.9748

F-stat $993.61(0.0000)$

The signs of estimated parameters are consistent with the above-formulated hypotheses. Classified loans increase in the phases of industrial production decline (and vice versa) and are sensitive to the amount of required interest payments. Hence the growth of lending interest rates influences not only the yields of commercial banks but also their costs.

\subsection{Summarization of partial empirical findings}

The above-formulated microeconomic model works with parameters in the form of marginal propensities. Taking into account the nature of the time series, part of our estimates was made after their transformation to relative changes while the resultant parameters are in the form of elasticities. For this reason an analytical calculation of 
marginal propensities was necessary in some parameters ( $c_{I R}$ and $\left.r_{R E P O S}\right)$ as the product of elasticity (estimated parameters) and average propensity (calculated for the studied period). After substituting into the condition of monetary policy efficiency operating under withdrawal of excess liquidity through reverse repo operations

$$
\begin{gathered}
\frac{\partial L}{\partial I R_{S}}=-\frac{2 \cdot w \cdot\left(1-g-r_{P M R}\right)}{l \cdot\left(1-c_{I R}\right) \cdot\left(1-r_{R E P O S}-r_{P M R}\right)+r_{R E P O S}-g}<0 \\
\frac{\partial L}{\partial I R_{S}}=-\frac{2 \cdot 601.3 b n . C Z K \cdot(1-0.4072-0.02)}{0.7420 \cdot(1-0.3142) \cdot(1-0.5242-0.02)+0.5242-0.4072}<0
\end{gathered}
$$

a conclusion can be drawn that this condition is satisfied.

Through an increase in repo rate the CNB can achieve a reduction of credit supply by commercial banks, which is a condition of the efficient performance of monetary policy within the framework of the so called credit channel. The converse is also true: through a decrease in repo rate the CNB may support higher supply of credits by commercial banks. Obviously, the central bank is limited in its expansive monetary policy by the zero rate bound.

\section{Conclusion}

In theory and in monetary policy textbooks commercial banks are considered as agents operating under a lack of liquidity that is supplied by a central bank. Currently, some transition economies do not fit in this traditional pattern as they have intervened in the foreign exchange market against the appreciation of domestic currency exchange rate. Balance sheets of central banks in many transition economies whose currencies have appreciated in the last years are characterized not only by the long foreign exchange position but also by the fact that their excess domestic liquidity sources are deposited by commercial banks with central banks in different forms of deposits. In the case of the CNB these are the two-week repo deposits of the domestic commercial banks that represent repo operations from the perspective of monetary policy. In our article we want to answer a question whether monetary policy based on changes in repo rate is as efficient in repo operations as in reverse repo operations. While the costs of commercial banks are rising if reverse repo rate increases, under restrictive monetary policy implemented through an increase in repo rate (withdrawal repo) the yields of commercial banks are rising. If restrictive monetary policy is implemented through an increase in reverse repo rate, the transmission mechanism of monetary policy is based on gradual transmission of the cost burden of commercial banks to their customers. If restrictive monetary policy is performed through an increase in repo rate (withdrawal repo), the arbitrage behaviour of commercial banks plays its role as they choose between various financial assets. Aiming at discussion and subsequent empirical verification of this problem a microeconomic model of commercial bank is formulated that represents the interest rate and credit 
transmission mechanism of monetary policy. This model results in the definition of preconditions of monetary policy efficiency under conditions of a profit maximizing bank. The conditions are derived alternatively for commercial banks operating under surplus and lack of liquidity, respectively. In the last chapter key parameters of the model are verified empirically by means of econometric equations that respect the time series properties in terms of their (non)stationarity. There arises a problem that the properties of some time series do not allow us to estimate the equations of the model for parameters in the form of marginal propensities. In some parameters we had to estimate parameters in the form of elasticities and subsequently to calculate analytically boundary slopes as the product of elasticity and average slope. After final substitution in the condition for monetary policy efficiency we arrived at a conclusion that CNB's monetary policy operating in conditions of excess liquidity withdrawal through reverse repo operations is efficient. In conditions of this country an increase in repo rate on reverse repo should lead to an increase in interest rates of commercial banks and to a reduction in the credit activity of commercial banks and hence to the successful implementation of CNB's restrictive monetary policy.

\section{References}

Arlt, J., Arltová, M. (2007), Ekonomické časové řady. Grada Publishing, a. s., Praha 2007.

Arlt, J., Radkovský, Š. (2000), "The Importance of Modelling and Forecasting of Time Series Volatility for the Control of Economic Processes." Politická ekonomie, 2000, Vol. 48, No. 1, pp. 38-61.

Bank of England (2000), "The Monetary Policy Committee. The Transmission Mechanism of Monetary Policy." Available at http://www.bankofengland.co.uk/

Brada, J., Brůna, K. (2004), „Analýza citlivosti referenčních úrokových sazeb PRIBOR na změny repo sazby České národní banky.“ Politická ekonomie, 2004, Vol. 52, No. 5, pp. 601-621.

Brůna, K. (2007), „Úrokový transmisní mechanismus a řízení úrokové marže bank v kontextu dezinflační politiky ČNB.“ Politická ekonomie, 2007, Vol. 55, No. 6, pp. 829-851.

Buliř, A. (1992), „Úroková sazba a rovnováha na úvěrovém trhu.“ Finance a úvěr, 1992, Vol. 42, No. 3, pp. 377-399.

Corvoisier, S., Gropp, R. (2001), "Bank Concentration and Retail Interest Rates." European Central Bank, Working Paper No. 72/2001.

Demirgüc-Kunt, A., Huizinga, H. (1999), "Determinants of Commercial Bank Interest Margins and Profitability: Some International Evidence." The World Bank Economic Review, Vol. 13, No. 2, pp. 379-408.

Dědek, O. (2000), "Měnový otřes 1997." ČNB, VP č. 15, Praha 2000.

Dvorný, Z. (2002). „Transmise klíčových úrokových sazeb v české ekonomice.“ Politická ekonomie, 2002, Vol. 50, No. 6., pp. 780-792.

Egert, B., Komárek, L. (2005), "Foreign Exchange Interventions and Interest Rate Policy in the Czech Republic: Hand in Glove?" CNB, Working Paper No. 7/2005.

Frait, J., Horská, H., Melecký, M. (2002), "Recese, deflace, bankovní krize a past likvidity v Japonsku." Politická ekonomie, Vol. 50, No. 2, 2002, pp. 263-280.

Garbade, K. D. (2006), "The Evolution of Repo Contracting Conventions in the 1980s." FRBNY Economic Policy Review, May 2006, pp. 27-41 
Geršl, A., Holub, T. (2006), "Foreign Exchange Interventions under Inflation Targeting: The Czech Experience." Contemporary Economic Policy, 2006, Vol. 24, No. 4 (October), pp. 475-491.

Holub, T. (2004), "Foreign Exchange Interventions Under Inflation Targeting: The Czech Experience." Prague, CNB Internal Research and Policy Notes, 2004, No. 1.

Ho, T. S. Y., Saunders, A. (1981), "The Determinants of Bank Interest Margin: Theory and Empirical Evidence." The Journal of Financial and Quantitative Analysis. 1981, Vol. 16, No. 4, pp. 581-600.

Horngren, L. (1995), "Monetary Policy in Theory and Practice." Sveriges Riksbank, Quarterly Review, 1995, No. 3, pp. 5-12.

Hušek, R. (1999), Ekonometrická analýza. Praha: Ekopress, 1999.

Izák, V. (1998), "Transmisní mechanismus měnové politiky - úvěrový kanál." Politická ekonomie, 1998, Vol. 46, No. 6, pp. 755-771.

Kodera. J., Mandel, M. (1997), "Transmisní mechanismy měnové politiky v podmínkách české ekonomiky.” ČNB, VP No. 76, Praha, 1997.

Korda, J. (2010), "Komparace nového konsensu jako teoretického rámce cílování inflace s postkeynesovskou ekonomii.." Politická ekonomie, 2010, Vol. 58, No. 1, pp. 92-104.

Kotlán, V. (1999), "Yield Curve in Theory and Practice of the Czech Interbank Market" (in Czech). Finance a úvěr, 1999, Vol. 49, No. 7, pp. 407-425.

Maddala, G.S., Lahiri, K. (2010), Introduction to Econometrics. 4th Edition. Willey.

Mandel, M.; Tomšík, V. (2012), "Otazníky nad kvantitativním uvolňování ECB." Bankovnictví.

Mirdala, R. (2009), "Interest Rate Transmission Mechanism of Monetary Policy in the Selected EMU Candidate Countries." MPRA Paper, 14072, University Library of Munich, Germany, 2009.

Mohany, M. S., Turner, P. (2008), "Monetary Policy Transmission in Emerging Market Economies: What Is New?" BIS Papers, No. 35, July 2008.

Moore, B. J. (2006), Shaking the Invisible Hand. Complexity, Endogenous Money and Exogenous Interest Rates. Basingstoke: New York Palgrave Macmillan, 2006.

Revenda, Z. (2010), Centrální bankovnictví. 3 ${ }^{\text {rd }}$ Edition. Praha: Management Press. 2010.

Sellon, G. H. (1984), "The Instruments of Monetary Policy." Economic Review, FRB Kansas City, May 1984, pp. 3-20.

Sellon, G. H. (1980), "The Role of the Discount Rate in Monetary Policy: A Theoretical Analysis. Economic Review, FRB Kansas City, June 1980, pp. 3 - 15.

Sojka, M. (2010), “Monetární politika Evropské centrální banky a její teoretická východiska pohledem post-keynesovské ekonomie." Politická ekonomie, 2010, Vol. 58, No. 1, pp. 3-19.

Šmídková, K. (1998), “Koruna Exchange Rate Turbulence in May 1997.” ČNB, VP No. 2, Praha, 1998.

Šmídková, K. (2002), "Transmisní mechanismus měnové politiky na počátku 3. tisíciletí." Finance a úvěr, 2002, Vol. No. 5, pp. 287-306.

Vencovský, F. (1997), Dějiny českého ekonomického myšlení do roku 1948. Brno: Nadace Universitas Masarykiana Edice Heureka, 1997.

Vencovský, F. (1999), "Utváření emisního mechanismu společné měny." Finance a úvěr, 1999, Vol. 49, No. 1, pp. 20-32. 